\title{
PERANAN KEARIFAN LOKAL DALAM PENDIDIKAN KARAKTER
}

\author{
Ulfah Fajarini \\ Universitas Islam Negeri (UIN) Syarif Hidayatullah Jakarta \\ Email: fajarini_ulfah@yahoo.com
}

\begin{abstract}
This article aims to examine on a wealth of local wisdom in Indonesia that plays a role in shaping the character education. Local wisdom will only be lasting if local knowledge implemented in concrete everyday life so that they can respond and answer the current times have changed. Local wisdom should also be implemented in state policy, for example by applying economic policy based on mutual cooperation and kinship as one manifestation of our local wisdom. To achieve that, state ideology (Pancasila) should be implemented in a variety of state policy. Thus, local knowledge will effectively function as a weapon-not just heritage-that equip people to respond and answer the current era. Preserving various elements of local wisdom, traditions and local institutions, including the norms and customs that are beneficial, can function effectively in character education, while doing study and enrichment with new wisdoms.
\end{abstract}

Keywords: kearifan lokal, pendidikan karakter

\begin{abstract}
Abstrak
Artikel ini bertujuan menelaah tentang kekayaan kearifan lokal di Indonesia yang berperan dalam membentuk pendidikan karakter. Kearifan lokal hanya akan abadi kalau kearifan lokal terimplementasikan dalam kehidupan konkret sehari-hari sehingga mampu merespons dan menjawab arus zaman yang telah berubah. Kearifan lokal juga harus terimplementasikan dalam kebijakan negara, misalnya dengan menerapkan kebijakan ekonomi yang berasaskan gotongroyong dan kekeluargaan sebagai salah satu wujud kearifan lokal kita. Untuk mencapai itu, perlu implementasi ideologi negara (Pancasila) dalam berbagai kebijakan negara. Dengan demikian, kearifan lokal akan efektif berfungsi sebagai senjata—tidak sekadar pusaka—yang membekali masyarakatnya dalam merespons dan menjawab arus zaman. Menggali dan melestarikan berbagai unsur kearifan lokal, tradisi dan pranata lokal, termasuk norma dan adat istiadat yang bermanfaat, dapat berfungsi secara efektif dalam pendidikan karakter, sambil melakukan kajian dan pengayaan dengan kearifan-kearifan baru.
\end{abstract}

\section{Kata kunci: kearifan lokal, pendidikan karakter}

\section{A. Pendahuluan}

Berbagai fenomena sosial yang muncul akhir-akhir ini pun cukup mengkhawatirkan. Fenomena kekerasan dalam menyelesaikan masalah menjadi hal yang umum. Pemaksaan kebijakan terjadi hampir pada setiap level institusi. Manipulasi informasi menjadi hal yang lumrah. Penekanan dan pemaksaan kehendak satu kelompok terhadap kelompok lain dianggap biasa. Hukum begitu jeli pada kesalahan tetapi buta pada keadilan. Tampaknya karakter masyarakat Indonesia yang santun dalam berperilaku, musyawarah mufakat dalam menyelesaikan masalah, local wisdom yang kaya dengan pluralitas, toleransi dan gotong royong, telah berubah wujud menjadi hegemoni kelompok-kelompok baru yang saling mengalahkan. Apakah kearifan lokal yang kita miliki seolah punah, dan hilang fungsinya dalam membentuk karakter di masyarakat? Tulisan ini akan mendiskusikan masalah tersebut.

\section{B. Kearifan Lokal}

Kearifan lokal adalah pandangan hidup dan ilmu pengetahuan serta berbagai strategi kehidupan yang berwujud aktivitas yang dilakukan oleh masyarakat lokal dalam menjawab berbagai masalah dalam pemenuhan 
kebutuhan mereka. Dalam bahasa asing sering juga dikonsepsikan sebagai kebijakan setempat "local wisdom" atau pengetahuan setempat "local knowledge" atau kecerdasan setempat "local genious".

Menurut Rahyono, kearifan lokal merupakan kecerdasan manusia yang dimiliki oleh kelompok etnis tertentu yang diperoleh melalui pengalaman masyarakat ${ }^{1}$ Artinya, kearifan lokal adalah hasil dari masyarakat tertentu melalui pengalaman mereka dan belum tentu dialami oleh masyarakat yang lain. Nilainilai tersebut akan melekat sangat kuat pada masyarakat tertentu dan nilai itu sudah melalui perjalanan waktu yang panjang, sepanjang keberadaan masyarakat tersebut.

Ilmuwan antropologi, seperti Koentjaraningrat, Spradley, Taylor, dan Suparlan, telah mengkategorisasikan kebudayaan manusia yang menjadi wadah kearifan lokal itu kepada idea, aktivitas sosial, $\operatorname{artifak}^{2}$. Kebudayaan merupakan keseluruhan pengetahuan yang dimiliki oleh sekelompok manusia dan dijadikan sebagai pedoman hidup untuk menginterpretasikan lingkungannya dalam bentuk tindakan-tindakannya sehari-hari.

Negara Indonesia sangat majemuk dan mempunyai petatah-petitih Melayu, bahasa kromo inggil Jawa, petuah yang diperoleh dari berbagai suku di Indonesia. Hal tersebut merupakan contoh keragaman ungkapan sukusuku bangsa yang menjadi bagian dari kearifan lokal, yang menjadi kendali dalam menjalankan kehidupan. Apa yang diutarakan dalam tulisan ini masih sangat minim, jika dibandingkan dengan seluruh suku-suku bangsa kita yang ada di nusantara (429 suku bangsa besar). Namun tulisan ini bermaksud mengetuk hati kita semua, bahwa kearifan budaya lokal berperan dalam pendidikan karakter bangsa. Berikut ini merupakan beberapa contoh kearifan lokal yang berkembang dalam kehidupan bangsa Indonesia. $^{3}$
1. Aceh: Udep tsare mate syahid (hidup bahagia, meninggal diterima Allah Swt), Hukom ngon adat lagge zat ngon sifeut (antara hukum dengan adat seperti zat dengan sifatnya).

2. Melayu (Deli, Kalimantan Barat, Sibolga, Sumatra Barat): Lain lubuk lain ikannya, di mana bumi diinjake di situ langit dijunjung.

3. Batak: Hasangapon, hagabeon, hamoraon, sarimatua (kewibawaan, kekayaan, keturunan yang menyebar, kesempurnaan hidup). Nilakka tu jolo saribon tu pudi (melangkah ke depan pertimbangkan ke belakang).

4. Sumatra Barat: Bulek ai dek pambuluah, bulek kato jo mupakkeke (bulat air karena pembuluh, bulat kata dengan mufakat); Adat ba sandi syara', syara' ba sandi kitabullah (adat berlandaskan hukum, hukum bersendikan kitab suci).

5. Wamena: Weak Hano Lapukogo (susah senang sama-sama); Ninetaiken O'Pakeat (satu hati satu rasa).

6. Bugis: Sipakatau (saling mengingatkan); Sipakalebbi (saling menghormati); Mali Siparappe, Rebba Sipatokkong (saling mengingatkan, saling menghargai, saling memajukan).

7. Manado: Baku Beking Pandei (saling memandaikan satu sama lainnya).

8. Minahasa: Torang Samua Basudara (kita semua bersaudara); Mapalus (gotong royong); Tulude-Maengket (kerja bakti untuk rukun), Baku-baku bae, bakubaku sayang, baku-baku tongka, bakubaku kase inga (saling berbaik-baik, sayang menyayangi, tuntun-menuntun, dan ingat mengingatkan); Sitou Timou, Tumou Tou (saling menopang dan hidup menghidupkan: manusia hidup dan untuk manusia lain).

9. Bolaang Mangondow: Momosat (gotong royong); Moto tabian, moto tampiaan, moto tanoban (saling mengasihi, saling memperbaiki dan saling merindukan).

10. Kaili: Kitorang bersaudara (persaudaraan); Toraranga (saling mengingatkan), Rasa Risi Roso Nosimpotobe (sehati, sealur pikir, setopangan, sesongsongan).

11. Poso: (Suku Pamona, Lore, Mori, Bungku dan Tojo/Una-Una, Ampana 
dan pendatang: Bugis, Makassar, Toraja, Gorontalo, Minahasa, Transmigrasi: Jawa, Bali, Nusa Tenggara): Sintunu Maroso (persatuan yang kuat: walau banyak tantangan, masalah, tidak ada siapapun yang dapat memisahkan persatuan warga Poso tanpa memandang suku, agama, ras dan antargolongan).

12. Sulawesi Tenggara: Kolosara (supremasi sistem rukun dan pencegahan konflik), Samaturu (Bahasa Tolala): Bersatu, gotong royong, saling menghormati; Depo adha adhati (Muna): saling menghargai.

13. Bali: Manyama braya (semua bersaudara), Tat Twam Asi (senasib sepenanggungan), Tri Hita Karana (tiga penyebab kebahagiaan), yakni Pariangan (harmoni dengan Tuhan), Pawongan (harmoni dengan sesama manusia), dan Palemahan (harmoni dengan lingkungan alam).

14. Jambi: Lindung melindung bak daun sirih, Tudung menudung bak daun labu, Rajut merajut bak daun petai (saling tolong menolong/ saling menghargai).

15. Jawa Timur: Siro yo ingsun, ingsun yo siro (kesederajatan atau egalitarianism), Antarantaran ugo (persaudaraan).

16. Pandeglang: Saman yang berfungsi sebagai kesenian, tarekat; jalan zikir dan ketenangan hati, serta simbol-simbol yang mempunyai kekuatan magis. ${ }^{4}$ Melalui kegiatan Saman masyarakat Pandeglang dapat menciptakan keharmonisan, kerukunan yang bersifat gotong royong dalam membangun kebersamaan sosial dan keagamaan di antara warganya, terutama bagi warga kelompok Saman, yang mengarah pada kehidupan bersama.

17. Kalimantan Selatan: Kayub baimbai (bekerjasama), Gawi sabumi (gotong royong), Basusun Sirib (keutuhan), Menyisir sisi tapih (introspeksi).

18. Dayak Kanayatri: Adil ka'talimo, bacuramin ka'saruga, ba sengat ka'jubata (adil sesama, berkaca surgawi, bergantung pada Yang Esa); Rumah Betang (bersama dan saling tenggang); Handep-babaring burung (nilai

\footnotetext{
4 Neneng Habibah. "Fungsi Saman Pada Masyarakat Pandeglang (Studi Kasus di Desa Giri Jaya Kecamatan Saketi dan Desa Batu Ranjang Kecamatan Cipeucang Kabupaten Pandeglang)," dalam Jurnal PENAMAS, Vol. XXI, No.1, Th 2008. h. 88.
}

kebersamaan dan gotong royong); Betang (semangat rumah panjang).

19. Dayak Bekati: Janji baba's ando (janji harus ditepati); Janji pua' take japu (jangan janji sekedar kata-kata).

20. Dayak Bahau: Murip ngenai (makmur sejahtera); Te'ang liray (unggul di antara sesama: kompetisi sehat).

21. Provinsi Nusa Tenggara Barat: Saling Jot (saling memberi), Saling pelarangin (saling melayat), Saling ayon (saling mengunjungi; silahturahmi), Saling ajinin (saling menghormati), Patut (baik, terpuji, hal yang tidak berlebih-lebihan), Patuh (rukun, taat, damai, toleransi, saling harga menghargai), Patju (rajin giat, tak mengenal putus asa), Tatas, Tuhu, Trasna (berilmu, berakhlak/etika, bermasyarakat).

22. Sasak (Lombok): Bareng anyong jari sekujung (bersama-sama lebur dalam satu), Embe aning jarum ito aning benang (ke mana arah jarum ke situ arah benang), Endang kelebet laloq leq impi (jangan terlalu terpesona oleh mimpi), Endaq ngegaweh marak sifat cupak (jangan memakai atau bersifat seperti cupak), Endaq ta beleqan ponjol dait kelekuk. (jangan lebih besar tempat nasi dari pada tempat beras), Endaq ta ketungkulan dengan sisok nyuling (jangan terlena dengan siput menyanyi), Idepta nganyam memeri, beleqna embuq teloq (seperti usaha memelihara anak itik, sesudah besar memungut telurnya), Keduk lindung, bani raok (berani cari belut harus berani kena lumpur), Laton kaynq pasti tebaban isiq angin (setiap pohon pasti dilanda oleh angin).

23. Mbojo (Bima): Bina kamaru mada ro kamidi ade, linggapu sedumpu nepipu ru boda (janganlah menidurkan mata dan berdiam diri, perbantallah kayu dan perkasurlah duri kaktus), Arujiki jimba wati loa reka ba mbe-e (rejeki domba tidak bisa didapat oleh kambing), Ngaha rawi pabu (berkata, berkarya hendaklah menghasilkan kenyataan).

24. DIY/Yogyakarta: Alon-alon asal kelakon (biar pelan asal selamat: kehati-hatian), Sambatan (saling membantu).

25. Solo Jawa Tengah: Ngono yo ngono neng ojo ngono (gitu ya gitu tapi jangan gitu), 
Mangan ora mangan yen ngumpul (makan tidak makan ngumpul).

26. Lampung: Sakai samboyan (sikap kebersamaan dan tolong menolong), Alemui nyimah (menghormati tamu), Bejuluk Beadok (memberi gelar/julukan yang baik kepada orang).

27. Bengkulu dan Rejang Lebong: Adat bersendai sorak, sorak bersendai kitabulloh (mirip Sumatra Barat), Tip-tip ade mendeak tenaok ngen tenawea lem Adat ngen Riyan Cao (setiap ada tamu ditegur sapa dengan adat dan tata cara), Di mana tembilang dicacak di situ tanah digali (Bengkulu), Naek ipe bumai nelat, diba lenget jenunjung (Rejang lebong, mirip Melayu), Titik mbeak maghep anok, tuwai ati tau si bapake (kecil jangan dianggap anak, tua belum tentu dia bapak), Kamo bamo (kekeluargaan dan mengutamakan kepentingan orang banyak), Amen ade dik. rujuak, mbeak udi temnai benea ngen saleak, kembin gacang sergayau, panes semlang sisengok, sileak semlang si betapun (jika ada musibah, jangan mencari kambing hitam, dinginkan hati yang panas, luka agar bertangkup dan tidak berdarah).

Tradisi Tabot, merupakan salah satu upacara tradisional di Kota Bengkulu "upacara Tabot", yaitu suatu perayaan tradisional yang dilaksanakan dari tanggal 1 sampai dengan tanggal 10 Muharam setiap tahun untuk memperingati gugurnya Hasan dan Husein cucu Nabi Muhammad Saw oleh keluarga Yazid dari kaum Syiah, dalam perang di Karbala pada 61 Hijriah $^{5}$. Pada perayaan Tabot seperti perayaan Sekaten di Yogyakarta, dilaksanakan berbagai pameran serta lomba ikan-ikan, telong-telong serta kesenian lainnya yang diikuti oleh kelompok-kelompok kesenian yang ada di Propinsi Bengkulu sehingga menjadi ajang hiburan rakyat dan menjadi salah satu kalender wisata tahunan. Tabot sebagai local genius berperan sebagai perimbangan (counterbalance) terhadap pengaruh desakan dari luar yang begitu gencar. Local genius di sini dapat diartikan sebagai

\footnotetext{
Harapandi Dahri, “Tabot dan Konstribusinya Dalam Pengembangan Kerukunan Umat Beragama" dalam Penamas, Agama dan Multikultur. Vol. XXI No.
} $1-$ Th. 2008 , h.51. kecerdasan orang-orang setempat untuk memanipulasi pengaruh kebudayaan luar dan budaya yang telah ada menjadi wujud baru yang lebih indah, lebih baik serta serasi sesuai selera setempat dan sekaligus merupakan bentuk spesifik atau jati diri daerah itu sendiri.

28. Sampang (Madura): Abantal ombak asapo' angina (berbantal ambal, berselimut angin), Lakona-lakone, kennengga kennengge (kerjakan dengan baik apa yang menjadi pekerjaanmu dan tempati dengan baik pula apa yang telah ditetapkan sebagai tempatmu), Todus (malu), Ango'an poteo tolang, e tebang potea mata (lebih baik putih tulang dari pada putih mata).

29. Ambon (Maluku): Pela Gandong (saudara yang dikasihi, Penguatan persaudaraan lewat kegotong-royongan dalam kehidupan), Gendong beta-gendongmu jua (deritaku deritamu juga).

Di bawah ini dideskripsikan kearifan lokal di Maluku Utara, yang diutarakan lebih detail dari contoh suku-suku lainnya yang telah disebutkan di atas. ${ }^{6}$ Sebagaimana diketahui bahwa di daerah Maluku Utara sebagai daerah bekas kesultanan meninggalkan beberapa filosofis, budaya, dan beberapa ajaran dasar yang melandasi tingkah laku dalam kehidupan bermasyarakat.

Soa (kampung) merupakan sebuah tatanan sosial yang demokratis, karena sangat egaliter dan akomodatif terhadap berbagai aliran dan keyakinan keagamaan. Secara keseluruhan tatanan ini bertumpu pada falsahah "Jou $S e$ Ngofa Ngare", yang merupakan common platform yang akomodatif terhadap kemajemukan.

Legu Gam, adalah pesta rakyat memperingati hari ulang tahun Sultan. Dalam acara ini ditampilkan pesta seni budaya tari-tarian tradisional, pembacaan puisi, pameran kerajinan lokal, hingga kegiatan seminar nasional yang menghadirkan pembicara dari kalangan akademisi, politisi dan budayawan tingkat nasional. Semua unsur masyarakat dilibatkan tanpa melihat latar belakang suku dan agama.

6 Yusuf Asry. Menelusuri Kearifan Lokal Di Bumi Nusantara. Melalui Dialog Pengembangan Wawasan Multikultural Antara Pemuka Agama Pusat dan daerah di Provinsi Maluku Utara, Papua, Maluku). Jakarta: Badan Litbang dan Diklat Kementrian Agama 2010. h. 38-43. 
Adat se Atorang (adat dan aturan) dapat dikatakan sebagai prinsip kebersamaan, persatuan dan persaudaraan dalam bingkai: "Morimoi Ngone Futuru" (bersatu kita teguh); cinta, keadilan, kebenaran, kebebasan dan persaudaraan teraplikasikan dalam berbagai kehidupan. Misalnya, di bidang keagamaan, acara perkawinan dan kematian. Di bidang ekonomi seperti aktivitas bakti sosial, gotong royong dan membangun rumah. Adat ini dikenal dalam masyarakat Moloku Kie Raha. Adat ini masih berfungsi dalam berperilaku dan tindak tanduk dalam kehidupan bermasyarakat.

Falsafah "Jou Se Ngofa Ngare" yang disimbolkan dalam "Goheba depolo romdid" (dua kepala burung garuda), dan satu hati mengandung arti bahwa masyarakat Ternate sangat menghargai keanekaragaman kultural. Simbol ini juga melambangkan bahwa penguasa dan rakyat memiliki kesamaan derajat dan kesamaan tujuan demi tercapainya kesejahteraan bersama.

Kie Se Gam magogugu ma titi rara (enam sila dasar): (1). Adat se Atorang, merupakan hukum dasar yang dipatuhi dan disusun menurut kebiasaan yang dapat diterima masyarakat. (2). Istiadat se kasabang; Lembaga adat dan kekuasaannya menurut ketentuan. (3). Galib se Lakudi; kebiasaan lama yang menjadi pegangan suku bangsa diatur menurut sendi ketentuan. (4). Ngale se Dulu; bentuk budaya masing-masing suku bangsa dapat digunakan secara bersama sesuai dengan keinginan. (5). Sere se Diniru; tata kehidupan seni budaya dan kebiasaan yang timbul dalam pergaulan masyarakat yang diterima secara bersama. (6). Cing se Cingare; pasangan wanita pria merupakan kesatuan yang utuh dengan hak dan kewajiban masing-masing dijaga kelestariannya.

Keenam sila dasar ini menjadi ikatan yang menyatukan sistem kekerabatan dalam pergaulan masyarakat adat Moloku Kie Raha, khususnya Ternate. Kalau terjadi sengketa atau perselisihan dalam masyarakat maka sandaran penyelesaiannya dikembalikan kepada hukum dasar tersebut.

Sistem norma dan aturan yang berlaku dalam masyarakat didasarkan pada: (1) Adat se Atorang, (2) Cara se-Ngale, (3) Galep se Lukudi, (4) Cing Se Cingare, (5) Baso se Hormat, (6) Baso se
Rasai, dan (7) Duka se Cinta. Cing se Cingare yaitu manusia sebagai makhluk sosial mempunyai ketergantungan satu dengan yang lain. Jika ingin dihormati atau disayangi orang lain, maka hormati dan sayangi orang lain. Budaya ini mencerminkan semangat gotong royong, penuh persaudaraan dan kebersamaan atas dasar tolong menolong. Sifat ini tertuang dalam puisi rakyat (dalil Moro) yang berbunyi: No fo Makati nyinga (mari kita bertimbang kasih), Doka gosora se bua lawa (seperti pala dengan fulinya), Om doro foma momote (jatuh bangun kita bersama), Foma Gogoru foma dodora (berkasih mesralah di antara kita).

Baso se Hormat, yaitu penghormatan atau sapaan. Dalam pergaulan hidup seharihari banyak digunakan bahasa sapaan untuk menciptakan keakraban sesama. Sifat ini tertuang dalam syair pantun (Dolo Bololo): Dara tolefo mampila (burung merpati ku beri tanda), Soro gudu to nonako (terbang jauh aku kenali), Gudu Moju si to suba ( $\mathrm{m}$ a si h jauh sudah keberi hormat), Ri jou si to nonako (Tuanku maka kukenali).

Baso se rasai, memiliki makna toleransi spiritual, misalnya, salah satu warga membangun rumah tinggal, masyarakat sekitarnya tanpa dipanggil dan diminta akan datang membantunya, baik tenaga maupun materiil, sifat ini tertuang dalam puisi rakyat: Ngone doka dai lako (kita bagaikan kembang), Abu mafara fara (tumbuh hidup berpencar), Si ruburubu yomamoi-moi (terhimpun dalam satu genggaman), Doka saya rako moi (bagaikan serangkai kembang).

Duka se Cinta, mengandung arti mengenang atau turut merasakan penderitaan yang dialami seseorang. Jika ada suatu keluarga yang ditimpa musibah berupa kecelakaan, bencana alam, kerusuhan atau kematian, maka semua anggota masyarakat sekitarnya mereka merasakan seakan-akan peristiwa tersebut terjadi pada diri atau keluarganya. Sifat ini diungkapkan dalam syair pantun: Fira mo si saya gam (gadis adalah kembang negeri), Adat yo mabisa bira (adatnya, abang pelindungnya), Fira mina mi gogola (sakitnya si gadis itu), Marurano bira i nying (kasih si abang saja obatnya).

Di daerah Jailolo, Halmahera barat terdapat Filosofi Adili, Palihara dan Diayi. Adili artinya 
perlakuan yang adil terhadap semua pihak. Palihara artinya memelihara satu dengan yang lainnya, membagi apa yang dimiliki tanpa membedakan suku dan agama. Diayi artinya menjaga hubungan yang rukun, tanpa melihat latar belakang agama.

\section{Pendidikan Karakter}

Azra memberikan pengertian bahwa pendidikan merupakan suatu proses di mana suatu bangsa mempersiapkan generasi mudanya untuk menjalankan kehidupan dan untuk memenuhi tujuan hidup secara efektif dan efisien? ${ }^{7}$ Ditegaskan bahwa pendidikan lebih dari sekedar pengajaran. Pendidikan adalah suatu proses di mana suatu bangsa atau negara membina dan mengembangkan kesadaran diri di antara individu-individu. Jadi, pendidikan pada dasarnya merupakan upaya Peningkatan kemampuan sumber daya manusia supaya dapat menjadi manusia yang mandiri serta dapat berkonstribusi terhadap masyarakat dan bangsanya.

Proses pendidikan yang profesional dapat membentuk karakter peserta didik. Karakter dapat dimiliki apabila kita memiliki integritas. Menurut McCain, integritas adalah kesetiaan pada nurani dan kejujuran pada diri sendiri sehingga akan membentuk karakter ${ }^{8}$. Karena itu, inti dari integritas adalah kejujuran pada diri sendiri maupun kepada orang lain. Masih menurut McCain bahwa prinsip tersebut merupakan harta milik yang terpenting. Bukan penampilan, kemampuan, bakat, kenyamanan atau kenikmatan, pekerjaan, rumah, mobil, mainan, berapa banyak teman yang mereka miliki, atau berapa banyak uang yang mereka hasilkan, namun kejujuran merupakan harta yang tidak ternilai dapat memberikan ketenangan hidup. Oleh karena itu, McCain dalam bukunya "Karakter-Karakter yang Menggugah Dunia" mengisahkan individu yang memiliki karakter istimewa yang membawa hidup dan dunia mereka lebih baik. Karakter tersebut membawa keteguhan dalam menjalani kehidupan yang penuh tantangan, penuh semangat yang tinggi dan tidak mengenal lelah untuk mencapai cita-

\footnotetext{
Azyumardi Azra. Paradigma Baru Pendidikan Nasional: Rekonstruksi dan Demokratisasi. Jakarta: Kompas, 2002, h.4.

8 McCain, John \& Mark Salter. Karakter-Karakter yang Menggugab Dunia. Terj. T. Hermaya, Jakarta: Gramedia Pustaka Utama, 2009. h.50-53.
}

citanya. Dalam kisah sukses tokoh-tokoh, mereka pasti memiliki karakter yang istimewa dalam mengatasi permasalahan yang ada pada dirinya. Karakter-karakter tersebut seperti kejujuran, rasa hormat, kesetiaan, martabat, idealisme, berbudi luhur, kepatuhan, tanggung jawab, kerja sama, keberanian, kendali diri, kepercayaan diri, kelenturan, penuh harapan, cinta kasih, belas kasih, toleransi, pengampunan, kemurahan hati, keadilan, merendahkan diri, penuh syukur, humor, kesantunan, cita-cita, keingin tahuan, antusiasme, keunggulan, mencintai orang lain tanpa pamrih dan kepuasaan hidup.

Pengertian karakter merupakan standarstandar batin yang terimplementasi dalam berbagai bentuk kualitas diri'. Karakter diri dilandasi nilai-nilai serta cara berpikir berlandaskan nilai-nilai tersebut dan terwujud dalam perilaku. Indonesia Heritage Foundation merumuskan beberapa bentuk karakter yang harus ada dalam setiapindividu bangsa Indonesia, di antaranya adalah: cinta kepada Allah dan alam semesta beserta isinya, tanggung jawab, disiplin, mandiri, jujur, hormat dan santun, kasih sayang, peduli dan kerja sama, percaya diri, kreatif, kerja keras dan pantang menyerah, keadilan dan kepemimpinan, baik dan rendah hati, toleransi, cinta damai dan persatuan. Character Counts di Amerika mengidentifikasikan bahwa karakterkarakter yang menjadi pilar adalah: dapat dipercaya (trustroorthiness), rasa hormat dan perhatian (respect), tanggung jawab (responsibility), jujur (fairness), peduli (caring), kewarga negaraan (citizenship), ketulusan (bonesty), berani (courage), tekun (deligence), dan integritas. Sementara, karakter masyarakat Indonesia yang dimiliki adalah karakter santun dalam berperilaku, musyawarah mufakat dalam menyelesaikan masalah, toleransi dan gotong royong.

Istilah karakter diambil dari bahasa Yunani yang berarti 'to mark' (menandai), istilah ini lebih fokus pada tindakan atau tingkah laku ${ }^{10}$. Wynne menjelaskan adanya dua pengertian tentang karakter. Pertama, menunjukkan bagaimana seseorang bertingkah laku. Apabila seseorang berperilaku tidak jujur, kejam dan rakus, tentulah orang tersebut memanifestasikan

\footnotetext{
9 Sabar Budi Raharjo, "Pendidikan Karakter Sebagai Upaya Menciptakan Akhlak Mulia", dalam Jurnal Pendidikan dan Kebudayaan, Vol.16, No.3, Mei 2010, h.232

10 Ibid.
} 
perilaku buruk. Sebaliknya, apabila seseorang berperilaku jujur, suka menolong, tentulah orang tersebut memanifestasikan karakter mulia. Kedua, istilah karakter erat kaitannya dengan "personality". Seseorang baru bisa disebut 'orang yang berkarakter' (a person of character) apabila tingkah lakunya sesuai kaidah moral.

\section{Penutup}

Kearifan lokal adalah warisan masa lalu yang berasal dari leluhur, yang tidak hanya terdapat dalam sastra tradisional (sastra lisan atau sastra tulis) sebagai refleksi masyarakat penuturnya, tetapi terdapat dalam berbagai bidang kehidupan nyata, seperti filosofi dan pandangan hidup, kesehatan, dan arsitektur. ${ }^{11}$ Dalam dialektika hidup-mati (sesuatu yang hidup akan mati), tanpa pelestarian dan revitalisasi, kearifan lokal pun suatu saat akan mati. Bisa jadi, nasib kearifan lokal mirip pusaka warisan leluhur, yang setelah sekian generasi akan lapuk dimakan rayap. Sekarang pun tanda pelapukan kearifan lokal makin kuat terbaca. Kearifan lokal acap kali terkalahkan oleh sikap masyarakat yang makin pragmatis, yang akhirnya lebih berpihak pada tekanan dan kebutuhan ekonomi. Sebagai contoh, di salah satu wilayah hutan di Jawa Barat, mitos pengeramatan hutan yang sesungguhnya bertujuan melestarikan hutan/alam telah kehilangan tuahnya sehingga masyarakat sekitar dengan masa bodoh membabat dan mengubahnya menjadi lahan untuk berkebun sayur. ${ }^{12}$ Ungkapan Jawa tradisional, mangan ora mangan waton kumpul (biar tidak makan yang penting berkumpul [dengan keluarga]), sekarang pun makin kehilangan maknanya. Banyak perempuan di pedesaan yang berbondong-bondong mendaftarkan diri untuk bekerja di manca negara dengan risiko terpisah dari keluarga daripada hidup menanggung kemiskinan dan kelaparan.

Kearifan lokal hanya akan abadi kalau kearifan lokal terimplementasikan dalam kehidupan konkret sehari-hari sehingga mampu merespons dan menjawab arus zaman yang telah berubah. Kearifan lokal juga harus

\footnotetext{
11 Suyono Suyatno, Revitalisasi Kearifan Lokal sebagai Upaya Penguatan Identitas Keindonesiaan. http://badanbahasa.kemdikbud.go.id/lamanbahasa/ artikel/1366

12 Kompas, 23 April 2011
}

terimplementasikan dalam kebijakan negara, misalnya dengan menerapkan kebijakan ekonomi yang berasaskan gotong-royong dan kekeluargaan sebagai salah satu wujud kearifan lokal kita. Untuk mencapai itu, perlu implementasi ideologi negara (yakni Pancasila) dalam berbagai kebijakan negara. Dengan demikian, kearifan lokal akan efektif berfungsi sebagai senjata-tidak sekadar pusaka-yang membekali masyarakatnya dalam merespons dan menjawab arus zaman.

Revitalisasi kearifan lokal dalam merespons berbagai persoalan akut yang dihadapi bangsa dan negara, seperti korupsi, kemiskinan, dan kesenjangan sosial, hanya akan berjalan jika didukung oleh kebijakan negara yang disertai dengan keteladanan. Tanpa kedua hal tersebut, kearifan lokal hanya merupakan aksesori budaya yang tidak bermakna. Kearifan lokal di berbagai daerah pada umumnya mengajarkan budaya malu (jika berbuat salah). Akan tetapi, dalam realitas sekarang, budaya malu seolah telah luntur. Peraturan yang ada pun kadang-kadang memberi peluang kepada seorang terpidana atau bekas terpidana untuk menduduki jabatan publik. Karena itu, budaya malu sebagai bagian dari kearifan lokal semestinya dapat direvitalisasi untuk memerangi korupsi, apalagi dalam agama pun dikenal konsep halal-haram (uang yang diperoleh dari korupsi adalah haram).

Di antara berbagai penggerusan kearifan lokal saat ini, di sisi lain kita masih menyaksikan pemanfaatan kearifan lokal, misalnya di dunia medis terjadi pengembangan obat herbal yang merupakan warisan leluhur di bidang medis, yang kemudian disempurnakan dengan standar farmakologi yang berlaku. Jadi, itu adalah salah satu wujud kearifan lokal yang telah memperoleh revitalisasi dalam masyarakat.

Sementara itu, gotong royong sebagai wujud kearifan lokal kita tampaknya belum terimplementasikan dalam perekonomian nasional yang makin didominasi oleh asing dan perusahaan multinasional dengan semangat neoliberalisme dan neokapitalisme. Perekonomian nasional yang berpijak dan tumbuh dari rakyat setidaknya mencerminkan identitas dan nasionalisme kita. Ketergantungan ekonomi pada asing menyebabkan kita dengan mudah didikte oleh kekuatan ekonomi dan 
politik asing dan hal itu akan mencederai kedaulatan kita sebagai bangsa.

Menggali dan melestarikan berbagai unsur kearifan lokal, tradisi dan pranata lokal, termasuk norma dan adat istiadat yang bermanfaat dan dapat berfungsi efektif dalam pendidikan karakter, sambil melakukan kajian dan pengayaan dengan kearifan-kearifan baru. Mengacu pada teori Social Learning, bahwa sesungguhnya budaya merupakan pola perilaku yang dipelajari, artinya bahwa masyarakatpun dapat "tidak belajar untuk keras" alias mempunyai karakter yang baik. Kearifan lokal apabila diterjemahkan secara bebas dapat diartikan nilai-nilai budaya yang baik yang ada di dalam suatu masyarakat. Hal ini berarti, untuk mengetahui suatu kearifan lokal di suatu wilayah maka kita harus bisa memahami nilai-nilai budaya yang baik yang ada di dalam wilayah tersebut. Kalau mau jujur, sebenarnya nilai-nilai kearifan lokal ini sudah diajarkan secara turun-temurun oleh orang tua kita kepada kita selaku anak-anaknya. Budaya gotong royong, saling menghormati dan tepa salira merupakan contoh kecil dari kearifan lokal. Sudah selayaknya, kita untuk menggali kembali nilai-nilai kearifan lokal yang ada agar tidak hilang ditelan perkembangan jaman, dan menjadi karakter bangsa Indonesia.

\section{Daftar Pustaka}

Asry, Yusuf. Menelusuri Kearifan Lokal Di Bumi Nusantara. Melalui Dialog Pengembangan Wawasan Multikultural Antara Pemuka Agama Pusat dan daerah di Provinsi Maluku Utara, Papua, Maluku). Jakarta: Badan Litbang dan Diklat Kementerian Agama. 2010.

Azra, Azyumardi. Paradigma Baru Pendidikan Nasional: Rekonstruksi dan Demokratisasi. Jakarta: Kompas. 2002. H.6.

Budi Raharjo. Sabar "Pendidikan Karakter Sebagai Upaya Menciptakan Akhlak Mulia", dalam Jurnal Pendidikan dan Kebudayaan, Vol.16, No.3, Mei 2010. H.232.
Dahri, Harapandi. "Tabot dan Konstribusinya Dalam Pengembangan Kerukunan Umat Beragama" dalam Penamas, Agama dan Multikultur. Vol. XXI No. 1 - Th. 2008. H.51.

Habibah. Neneng. "Fungsi Saman Pada Masyarakat Pandeglang (Studi Kasus di Desa Giri Jaya Kecamatan Saketi dan Desa Batu Ranjang Kecamatan Cipeucang Kabupaten Pandeglang)," dalam Jurnal PENAMAS, Vol.XXI, No.1, Th 2008. $\mathrm{H}, 88$.

John, McCain \& Mark Salter. Karakter-Karakter yang Menggugah Dunia. Terj. T. Hermaya, Jakarta: Gramedia Pustaka Utama. 2009.

Koentjaraningrat. Pengantar Ilmu Antropologi. Jakarta: Aksara Baru. 2009.

Rahyono. F.X. Kearifan Budaya dalam Kata. Jakarta: Wedatama Widyasastra. 2009

Sukarata, Made. "Pengenalan dan Pemahaman Local Genius Menghadapi Era Globalisasi di Indonesia", dalam Nirmala, Surabaya, Jurusan Desain Komunikasi Visual, Fakultas Seni dan Desain-Universitas Kristen Petra, Vol. 1, No.1. Januari 1999. H.43.

Melalatoa, M. Yunus. Ensiklopedi Suku Bangsa di Indonesia. Jilid A-Z. Jakarta Departemen Pendidikan dan Kebudayaan. 1995.

Suyatno, Suyono. Revitalisasi Kearifan Lokal sebagai Upaya Penguatan Identitas Keindonesiaan. http://badanbahasa.kemdikbud.go.id/ lamanbahasa/artikel/1366.

Tumanggor, Rusmin. "Pemberdayaan Kearifan Lokal Memacu Kesetaraan Komunitas Adat Terpencil" dalam Jurnal Penelitian dan Pengembangan Kesejabteraan Sosial. Vol.12. No.01, januari-April 2007. H.912. 